\title{
Stroke Prevention: Editorial to accompany June issue of SVN
}

\section{J David Spence}

To cite: Spence JD. Stroke Prevention: Editorial to accompany June issue of SVN. Stroke and Vascular Neurology 2018;3: e000171. doi:10.1136/ svn-2018-000171

Received 7 June 2018 Accepted 7 June 2018

\section{Linked}

- http://dx.doi.org/10.1136/ svn-2017-000129

- http://dx.doi.org/10.1136/ svn-2017-000130

- http://dx.doi.org/10.1136/ svn-2017-000138

> http://dx.doi.org/10.1136/ svn-2018-000143

> http://dx.doi.org/10.1136/ svn-2018-000146

> http://dx.doi.org/10.1136/

svn-2018-000155

- http://dx.doi.org/10.1136/

svn-2018-000156

> http://dx.doi.org/10.1136/

svn-2018-000168

- http://dx.doi.org/10.1136/

svn-2018-000173

Check for updates

Stroke Prevention and Atherosclerosis Research Centre, Robarts Research Institute, Western University, London, Ontario, Canada

Correspondence to Profosser J David Spence; dspence@robarts.ca
This issue of Stroke and Vascular Neurology focuses on stroke prevention, a problem that is of paramount importance. Stroke is highly age-related, so prevention of stroke could have a major impact, with the ageing of the population in Western countries. Furthermore, in China the opportunity is particularly important, as the risk of stroke and coronary disease has increased markedly with the dietary changes that have resulted from increased prosperity. Prevention is far more cost-effective than treatment of stroke (approximately 10-fold).

In 2007, I estimated with my colleague Dr Daniel Hackam that a combination of therapies could reduce stroke recurrence by $\sim 80 \%{ }^{1}$ Most physicians vastly underestimate the importance of lifestyle issues; smoking cessation and a Mediterranean diet rank at the top of interventions in stroke prevention. In the past few years, there have been major advances that should make it possible to do even better.

There is better evidence that the Mediterranean diet reduces the risk of stroke. Even in primary prevention, the reduction of stroke was nearly half; in secondary prevention (because the risk is higher), the absolute risk reduction should be even greater.

Advances in diet, antiplatelet and anticoagulant therapy, B vitamins to lower homocysteine for stroke prevention, ${ }^{2}$ lipid-lowering therapy for stroke prevention, improvements in control of resistant hypertension, percutaneous closure of patent foramen ovale, better risk stratification in asymptomatic carotid stenosis and appropriate implementation of endarterectomy and stenting in patients with carotid stenosis can all have important impacts on preventing stroke.

The future for stroke prevention is very bright, but getting it all right is a tall order. We hope that this issue of Stroke and Vascular Neurology will help physicians to do so.

Funding The author has not declared a specific grant for this research from any funding agency in the public, commercial or not-for-profit sectors.

Competing interests None declared.

Patient consent Not required.

Provenance and peer review Commissioned; internally peer reviewed.

Open access This is an open access article distributed in accordance with the Creative Commons Attribution Non Commercial (CC BY-NC 4.0) license, which permits others to distribute, remix, adapt, build upon this work non-commercially, and license their derivative works on different terms, provided the original work is properly cited and the use is non-commercial. See: http://creativecommons.org/licenses/by-nc/4.0/

(C) Article author(s) (or their employer(s) unless otherwise stated in the text of the article) 2018. All rights reserved. No commercial use is permitted unless otherwise expressly granted.

\section{REFERENCES}

1. Hackam DG, Spence JD. Combining multiple approaches for the secondary prevention of vascular events after stroke: a quantitative modeling study. Stroke 2007;38:1881-5.

2. Spence JD, Yi Q, Hankey GJ. B vitamins in stroke prevention: time to reconsider. Lancet Neurol 2017;16:750-60. 